O. D. TERESCHENKO, M. Y. PEREBIYNIS, I. V. KNYSH, O. V. VASYLETS, A. A. SOROCHENKO,

E. Y. SLOBODYANYUK, E. B. RUSANOV, O. V. BORYSOV, S. V. KOLOTILOV,

S. V. RYABUKHIN*, D. M. VOLOCHNYUK* (ENAMINE LTD, KYIV, NATIONAL ACADEMY OF SCIENCES OF UKRAINE, KYIV, AND TARAS SHEVCHENKO NATIONAL UNIVERSITY OF KYIV, UKRAINE)

Electrochemical Scaled-up Synthesis of Cyclic Enecarbamates as Starting Materials for Medicinal Chemistry Relevant Building Blocks

Adv. Synth. Catal. 2020, 362, 3229-3242, DOI: 10.1002/adsc.202000450.

\section{Multigram Electrosynthesis of Enecarbamates and Related Building Blocks}

Optimized Shono oxidation-elimination conditions:
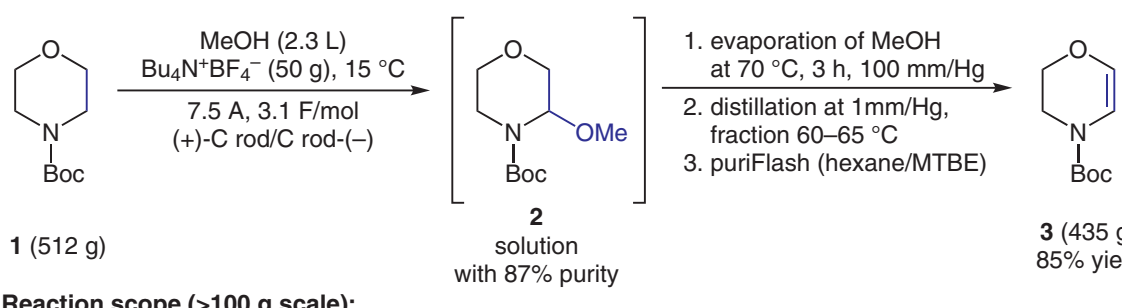

1. evaporation of $\mathrm{MeOH}$ at $70{ }^{\circ} \mathrm{C}, 3 \mathrm{~h}, 100 \mathrm{~mm} / \mathrm{Hg}$ 2. distillation at $1 \mathrm{~mm} / \mathrm{Hg}$, fraction $60-65^{\circ} \mathrm{C}$ 3. puriflash (hexane/MTBE) $\quad$ Boc

Reaction scope (>100 g scale):<smiles>O=C(Oc1ccccc1)N1C=CCCC1</smiles><smiles>CC(=O)C1CCC=CN1C(=O)OCc1ccccc1</smiles><smiles>CC(=O)OC(C)C1COC=CN1C(=O)O</smiles>

$4(87 \%$ yield $) \quad 5(73 \%$ yield $)$<smiles>CC(=O)C1C=CN(Br)CC1</smiles><smiles>CC(=O)N1C=CCCC1</smiles><smiles>CC(=O)N1C=CSCC1</smiles>

7 ( $85 \%$ yield)
Category

Synthesis of Heterocycles

Key words

electrochemistry

enecarbamates

Shono oxidation morpholines piperidines pyrazoles

Examples of gram-scale enecarbamate functionalization:<smiles>O=C(c1ccccc1)N1CCOCC1C(F)(F)F</smiles>

$10(53 \% \mathrm{cis})$<smiles>O=C(O)N1CCOC2C1C2(F)F</smiles>

11 (86\% yield)<smiles>O=CC1=CN(C(=O)c2ccccc2)CCO1</smiles>

$12(57 \%$ yield $)$<smiles>O=C(OCc1ccccc1)N1C=C(C(=O)C(F)(F)F)OCC1</smiles>

Boc

13 (72\% yield)<smiles>O=C(O)N1C=C(Br)CCC1</smiles>

14 (78\% yield)<smiles>NCCOc1c[nH]nc1C(F)(F)F</smiles>

15 (88\% yield)
Significance: Chemistry within a drug-discovery environment presents an interesting dichotomy in that whereas new chemical space is highly desirable, medicinal chemists typically rely on a suite of robust reactions for their synthetic endeavors, particularly when planning parallel (library) campaigns. Given this, the complexity and novelty of the molecules synthesized arise from the building blocks that are used, with a wide variety of diverse and unique collections of these becoming more accessible from commercial sources (A. Tomberg, J. Boström Drug Discov. Today 2021, 25, 2174). The current report describes a simple cost-effective electrochemical synthesis of a series of cyclic enecarbamates on a multigram scale and their subsequent elaboration into diverse functionalized building blocks for utilization in drug-discovery programs.

SYNFACTS Contributors: Paul Richardson (Pfizer)
Comment: Prior to this report, the dihydrooxaazine 3 was unknown in the literature and, of the compounds reported, only the tetrahydropyridine 4 was commercially available. Optimization of the Shono oxidation focused on the development of a multigram protocol as opposed to a systematic evaluation of reaction variables. Notably, an electrolysis galvanostatic mode was employed on scale because of the ease of controlling a constant current as opposed to a constant potential. $\mathrm{Bu}_{4} \mathrm{~N}^{+} \mathrm{BF}_{4}{ }^{-}$ was selected as the electrolyte owing to its ability to catalyze the subsequent conversion of $\mathbf{2}$ into $\mathbf{3}$, and inexpensive graphite electrodes were used. The enecarbamates were subjected to $[2+1]$ cycloadditions $(\mathbf{1 0}, \mathbf{1 1})$, and electrophilic substitutions $(12,13)$, with further functionalization of the latter products achieved through elimination (14) or recyclization after deprotection and treatment with hydrazine (15). 